\title{
Effect of E-Procurement Implementation on the Procurement Accountability of Health Facilities in Bantaeng, Indonesia
}

\author{
Ahmad Harakan ${ }^{1}$, Shinta Alfiah Nur ${ }^{1}$, Nuryanti Mustari ${ }^{1}$, Mergen Dyussenov ${ }^{2}$ \\ \{ahmad.harakan@unismuh.ac.id\} \\ Universitas Muhammadiyah Makassar ${ }^{1}$ \\ Academy of Public Administration under the President of the Republic of Kazakhstan ${ }^{2}$
}

\begin{abstract}
E-procurement is the process of procurement of goods and services electronically using information technology. Accountability is the responsibility of creating oversight through the distribution of power in various government institutions so as to reduce the accumulation of power and create a situation of mutual care. The study aims to determine the response to the implementation of e-procurement, to the accountability of procurement of health facilities in the Disaster Preparedness Brigade and whether the implementation of e-procurement has an effect on the accountability of procurement of disaster preparedness health facilities in the Bantaeng district. This research uses quantitative methods with the type of survey research. The results of this study indicate the application of E-procrement in the Bantaeng District Health Office in the good category. The response to accountability in the provision of health facilities in the Disaster Preparedness Brigade in Bantaeng District was very good. The Effect of EProcurement Implementation on the Accountability of Procurement of Health Facilities in the Disaster Preparedness Brigade in Bantaeng Regency has a strong influence. Of course, so it should get the attention of the authorities in its application. The application of e-procurement that has not been maximized does not merely occur because of a lack of interest in the bureaucratic apparatus, but occurs due to other factors.
\end{abstract}

Keywords: E-procurement, accountability, health facilities

\section{Introduction}

The implementation of good governance is the aspiration and hope of the Indonesian people. Good governance according to the United Nations Development Program (UNDP) is the implementation of government that does not only involve the government, but involves 3 actors, namely the state or government, the private sector, and the community [1]-[3]. The realization of Good Governance can be carried out well if the implementation of e-government practices as a form of government innovation in conditioning a government organization to be more effective and efficient, which takes advantage of technological advances. One of the efforts to implement e-government to achieve good governance is the implementation of electronic procurement of government goods and services [4]. 
The facts show that the level of corruption in the goods / services procurement sector is in the top position, namely 66 cases. The large number of corruption crimes committed in the procurement of ordinary goods / services shows that the actual accountability and transparency of the government still need to be questioned, and no follow-up has been taken for effective prevention in order to minimize corruption [5]. Therefore, in 2010 the President of Indonesia strictly regulated in Presidential Petition No. 54 of 2010 that the government procurement of goods / services 2 is required to be carried out by e-procurement, that is, provincial, district / city governments are required to conduct procurement of goods / services electronically (e-procurement).

One of the districts that carries out the procurement of goods and services electronically (eprocurement) is Bantaeng Regency. Bantaeng Regency is one of the best implementers of the electronic system for goods and services auction (e-procurement) at the regency and municipal level in Indonesia in 2012. However, in terms of its technical implementation, there are still some problems. Because of this, to see the implementation of the procurement of goods and services (e-procurement) in Bantaeng Regency can be said to be running well or not, it is necessary to review the extent of the influence of e-procurement in the procurement of goods / and services [6].

In government activities, the government is competing to make use of information technology in all aspects of its activities. One of them is E-Procurement, which is the process of procuring goods and services electronically using information technology. The Bantaeng City Government has implemented the use of e-procurement since 2010.

The implementation of e-procurement is based on Law Number 11 of 2008 concerning Electronic Information and Transactions, which states that the use of information technology contributes greatly to the growth and trade of the national scale economy for the welfare of the community. which has an impact on increasing the effectiveness and efficiency of public services.

Figure 1. Disaster Alert Brigade Office and Services

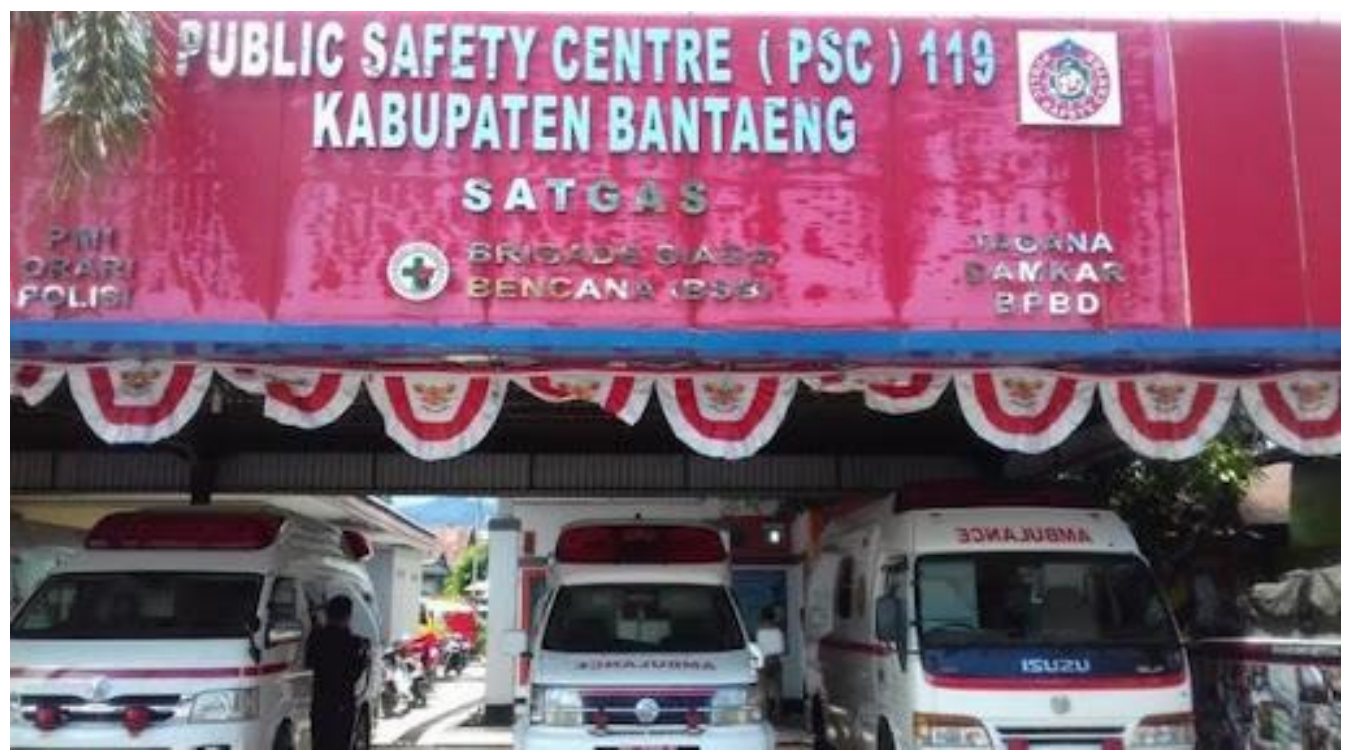

Source: South Sulawesi Province Website [7] 
In a period of several years of e-procurement implementation, several problems were found in the process. First, there are obstacles in the technology sector. It can be seen from internet access that has not been spread thoroughly to all regions. Also found was the inability to use electronic goods and services provided to the Disaster Alert Brigade [8].

The next problem is in the aspect of participation. In the implementation of e-procurement, the participation of the community has not been realized as expected. This is due to the lack of socialization to the public regarding the e-procurement policy implemented by the Bantaeng City Government. Accountability is one of the main elements in realizing good governance [9]. Accountability is an interesting topic for government, because accountability has evolved from a traditional nature (financial accountability) into several principles, namely administrative accountability, political accountability, and social accountability [10], [11].

The scope of transparency and accountability must cover several levels of policy starting from policy formulation, decision making, to implementation that occurs in all institutions. This can be done in the Disaster Alert Health Brigade in Bantaeng Regency by realizing all the indicators contained in transparency [8].

This description explains that accountability will be able to improve good governance, because there is accountability or transparency occurs from the party given the mandate to the mandate. Through accountability, oversight of power from government institutions is created. Referring to research conducted by Helmy Prasetyo Yuwinanto explaining about the implementation of e-procurement in the city of Surabaya with the results of the implementation of e-procurement in the city of Surabaya is influenced by communication factors, resources, implementors' disposition / attitude, and bureaucratic structure [12].

Other research conducted by Kodar Udoyono explained that there are two factors that influence e-procurement accountability, namely, the inhibiting factor for E-Procurement accountability is the lack of monitoring in field implementation, abuse of authority in the process of procuring goods and services, there are still contract irregularities in the implementation of E-Procurement, collusion between partner governments and implementation, manipulation in E-procurement implementation, and human resource weaknesses [13]. Meanwhile, the supporting factors are political will, oversight of legislative institutions and supervision of non-governmental organizations [13]. With the large amount of previous literature on the above background, the authors are interested in writing about EProcurement so that researchers are interested in studying the effect of E-Procurement implementation on the procurement accountability of health facilities in Bantaeng, Indonesia.

\section{Method}

This type of research uses quantitative research. The variables studied were e-procurement as the independent variable $(\mathrm{X})$ and the accountability of the Disaster Alert Brigade health facility processing as the dependent variable (Y). The time in this research was conducted for two months, namely in August - September 2019 or after the research permit had been issued by the faculty. This research was conducted in Bantaeng Regency, the researcher took this location on the grounds that in Bantaeng Regency there was data needed by the researcher so that it was possible to use it as an object of research.

The population in this study were 20 employees of the Health Office in Bantaeng Regency and 20 members of the implementation team of the Disaster Alert Brigade in Bantaeng Regency. The sampling technique used was purposive sampling. This technique was chosen with the aim that the sample taken could represent the desired population characteristics. 
This research uses survey research type. This survey method is a research that takes a sample from the population and uses a questionnaire as the main data collection tool. To obtain data or information, researchers used primary data collection techniques through observation and questionnaires.

Observation is the activity of directly observing the object of research by noting the symptoms found in the field and the questionnaire is a number of written questions that are used to obtain information from respondents. In addition, the authors use secondary data collection techniques through literature studies, namely data collection obtained from scientific books, expert opinions that have relevance to the problem being researched and documentary studies, namely data collection obtained using written notes located at research sites and other sources.

Data from the results of distributing questionnaires to respondents is done by simply answering questions in the available column using a Likert scale, which is giving 5 alternative answers including, Strongly Agree given a score of 5, agree given a score of 4, neutral is given a score of 3, Disagree given a score 2, and strongly disagree was given a score of 1 .

The instrument validity test will be carried out by the researcher to test whether the constructs or characteristics in this study, namely the e-procurement variables and procurement accountability, can be measured accurately by the indicators. As many as 40 respondents, by comparing the calculated $r$ value with the $r$ value of the Product Moment

table. If the calculated $r$ value $\geq r$ table then the indicator or questionnaire question is said to be valid, and vice versa.

The internal consistency reliability test will be carried out by the researcher to test the consistency of the items in the research questionnaire with the Sperman Brown Belah Dua technique. Reliability testing is enough to compare ralpha with a value of 0.6. If $\mathrm{r}$ alpha $\geq 0.6$ then the indicator or questionnaire question is said to be reliable, and vice versa.

This study uses several data analysis techniques, namely Descriptive Statistical Analysis Techniques, to analyze data by describing or describing the data that has been collected. Then the Correlation Coefficient Analysis Technique, to determine the closeness of the relationship between e-Procurement with procurement accountability and to know the relationship that occurs. This correlation coefficient uses the Pearson product moment. Finally, Simple Linear Regression Analysis Techniques, to see the effect of the e-procurement variable on the procurement accountability variable.

\section{Result and Discussion}

E-Government is a form of government innovation in conditioning a government organization to be more effective and efficient, which takes advantage of technological advances. Previous research has explained that to achieve good governance, the implementation of electronic government procurement of goods and services must be carried out [4], [14].

Procurement of goods and services through an electronic system, namely e-procurement is a tool to assist in carrying out procurement activities, besides that what is meant by electronic procurement is the use of electronic networks in the implementation of goods and services procurement (internet or intranet networks) or Electronic Data Interchange (EDI) [15].

To strengthen the literature, refer to research conducted by Helmy Prasetyo Yuwinanto in his explanation of the Implementation of E-Procurement in the City of Surabaya where the results of the Implementation of E-Procurement in the City of Surabaya are influenced by 
Communication Factors, Resources, Disposition / Attitude of Implementers, and Bureaucratic Structure [12].

In carrying out the e-procurement process, accountability is necessary. Researchers reveal that accountability is a degree that shows the amount of responsibility of officials for policies and public service processes carried out by the government bureaucracy. So it is hoped that in the application of this accountability, bureaucratic officials are capable of managing regional finances so that corruption, collusion and nepotism can be overcome [16], [17].

One of the districts that carries out the procurement of goods and services electronically or e-procurement is Bantaeng Regency. Bantaeng Regency is one of the best implementers of the electronic system for auctioning goods and services based on E-procurement throughout Indonesia in 2012. However, in terms of its technical implementation, there are still some problems. Therefore, to see the implementation of the procurement of goods and services (eprocurement) in Bantaeng Regency can be said to be running well or not, it is necessary to review the extent of the influence of e-procurement in the procurement of these goods and services.

Table 1. Respondents' Responses about E-Procurement (X)

\begin{tabular}{|c|c|c|c|c|c|c|c|c|c|c|c|}
\hline \multirow{3}{*}{ Questions } & \multicolumn{10}{|c|}{ Respondents Respons } & \multirow[t]{3}{*}{ Score } \\
\hline & \multicolumn{2}{|c|}{ SD } & \multicolumn{2}{|c|}{ D } & \multicolumn{2}{|c|}{ DF } & \multicolumn{2}{|c|}{$\mathbf{A}$} & \multicolumn{2}{|c|}{ SA } & \\
\hline & $\sum$ & $\%$ & $\sum$ & $\%$ & $\sum$ & $\%$ & $\sum$ & $\%$ & $\sum$ & $\%$ & \\
\hline Q 1 & - & - & 2 & 5,0 & 7 & 17,5 & 20 & 50,0 & 11 & 27,5 & 160 \\
\hline Q 2 & - & - & 1 & 2,5 & 9 & 22,5 & 17 & 42,5 & 13 & 32,5 & 162 \\
\hline Q 3 & - & - & 2 & 5,0 & 9 & 22,5 & 17 & 42,5 & 12 & 30,0 & 159 \\
\hline Q 4 & - & - & 3 & 7,5 & 4 & 10,0 & 17 & 42,5 & 16 & 40,0 & 166 \\
\hline Q 5 & - & - & - & - & 7 & 17,5 & 14 & 35,0 & 19 & 47,5 & 172 \\
\hline Q 6 & - & - & - & - & 7 & 17,5 & 18 & 45,0 & 15 & 37,5 & 168 \\
\hline Q 7 & - & - & 2 & 5,0 & 7 & 17,5 & 20 & 50,0 & 11 & 27,5 & 160 \\
\hline Q 8 & - & - & 1 & 2,5 & 8 & 20,0 & 18 & 45,0 & 13 & 32,5 & 163 \\
\hline Q9 & - & - & 2 & 5,0 & 8 & 20,0 & 24 & 60,0 & 6 & 15,0 & 154 \\
\hline Q 10 & - & - & 2 & 5,0 & 7 & 17,5 & 16 & 40,0 & 15 & 37,5 & 164 \\
\hline Q 11 & & & 1 & 2,5 & 14 & 35,0 & 13 & 32,5 & 12 & 30,0 & 156 \\
\hline Q 12 & & & 5 & 12,5 & 12 & 30,0 & 10 & 25,0 & 13 & 32,5 & 151 \\
\hline Q 13 & & & 1 & 2,5 & 4 & 10,0 & 16 & 40,0 & 19 & 47,5 & 173 \\
\hline \multicolumn{11}{|c|}{ Total Score } & 2108 \\
\hline \multicolumn{11}{|c|}{ Average } & 162.1 \\
\hline
\end{tabular}

Source: Data processing from Questionnaire (2019)

Table 1 shows that there are several factors that influence e-procurement so that its implementation has been fully implemented. One of the supporting factors for the implementation of e-procurement is the speed with which the government sees business opportunities with the ability of the bureaucratic apparatus to interact with the availability of existing internet facilities. However, there are factors that hinder the implementation of eprocurement, namely unstable internet networks, human resources, blackout of lights and others. 
Table 2. Respondents' Responses about Accountability (Y)

\begin{tabular}{|c|c|c|c|c|c|c|c|c|c|c|c|}
\hline \multirow[t]{3}{*}{ Questions } & \multicolumn{10}{|c|}{ Respondents Respons } & \multirow[t]{3}{*}{ Score } \\
\hline & \multicolumn{2}{|c|}{ SD } & \multicolumn{2}{|c|}{ D } & \multicolumn{2}{|c|}{ DF } & \multicolumn{2}{|c|}{$\mathbf{A}$} & \multicolumn{2}{|c|}{ SA } & \\
\hline & $\sum$ & $\%$ & $\sum$ & $\%$ & $\sum$ & $\%$ & $\sum$ & $\%$ & $\sum$ & $\%$ & \\
\hline Q 1 & - & - & 2 & 5,0 & 9 & 22,5 & 17 & 42,5 & 12 & 30,0 & 159 \\
\hline Q2 & - & - & 1 & 2,5 & 4 & 10,0 & 19 & 47,5 & 16 & 40,0 & 170 \\
\hline Q3 & - & - & - & - & 8 & 20,0 & 12 & 30,0 & 20 & 50,0 & 172 \\
\hline Q4 & - & - & 2 & 5,0 & 7 & 17,5 & 16 & 40,0 & 15 & 37,5 & 164 \\
\hline Q 5 & - & - & 3 & 7,5 & 10 & 25,0 & 16 & 40,0 & 11 & 27,5 & 555 \\
\hline Q 6 & - & - & 2 & 5,0 & 11 & 27,5 & 16 & 40,0 & 11 & 27,5 & 156 \\
\hline Q 7 & - & - & 2 & 5,0 & 6 & 15,0 & 18 & 45,0 & 14 & 35,0 & 164 \\
\hline Q 8 & - & - & 1 & 2,5 & 12 & 30,0 & 21 & 52,5 & 6 & 15,0 & 152 \\
\hline Q9 & - & - & 1 & 2,5 & 14 & 35,0 & 13 & 32,5 & 12 & 30,0 & 156 \\
\hline \multicolumn{11}{|c|}{ Total Score } & 1448 \\
\hline \multicolumn{11}{|c|}{ Average } & 160.8 \\
\hline
\end{tabular}

Source: Data processing from Questionnaire (2019)

Based on the results of research at the Bantaeng District Health Office of $81.0 \%$, which shows that the implementation of accountability is in good judgment. This shows that there are several factors that affect accountability so that the implementation has been fully implemented. One of the supporting factors for the implementation of accountability is the attitude of responsibility given by the government to the bureaucratic apparatus at the Bantaeng District Health Office so that the implementation of the procurement of goods and services electronically can be monitored and monitored for progress. However, there are factors that hinder the implementation of accountability, namely the culture that develops in society where bureaucratic officials give priority to service to family and other colleagues.

Table 3. Model Summary

\begin{tabular}{|c|c|c|c|c|}
\hline Model & $\mathrm{R}$ & R Square & Adjusted R Square & $\begin{array}{l}\text { Std. Error of the } \\
\text { Estimate }\end{array}$ \\
\hline 1 & $.736^{2}$ & .541 & .529 & 4.420 \\
\hline
\end{tabular}

a. Predictors: (Constant), responsiveness

The simple regression equation model formula used in determining the influence of variable $\mathrm{X}$ on variable $\mathrm{Y}$ in this study is as follows:

$$
\begin{gathered}
\mathrm{Y}=\mathrm{a}+\mathrm{bX} \\
\mathrm{Y}=14.827+1.046(\mathrm{X}) \\
\mathrm{Y}=15.873
\end{gathered}
$$

Based on the regression equation above, it can be interpreted that the regression coefficient (b) is 1.046 which states that the independent variable or e-procurement (X) 93 has a positive 
effect on the dependent variable or accountability $(Y)$. Based on the results of $t$ count $>t$ table $(15,873>1,686)$ or significant $(\mathrm{Sig})$ of 0,000 is less than $<0.05$, so it means that hypothesis one (H1) is accepted. This means that the first hypothesis (H1) e-procurement has a significant effect on accountability in the Bantaeng District Health Office.

Table 4. Coeficients*

\begin{tabular}{|c|c|c|c|c|c|}
\hline \multirow[t]{2}{*}{ Model } & \multicolumn{2}{|c|}{$\begin{array}{l}\text { Unstandardized } \\
\text { Coeffisients }\end{array}$} & $\begin{array}{l}\text { Standardized } \\
\text { Coefficients }\end{array}$ & $\mathrm{T}$ & Sig. \\
\hline & $\mathrm{B}$ & Std.Error & Beta & & \\
\hline $1 \quad$ (Constant) & 14.827 & 5.698 & & 2.602 & .013 \\
\hline e-procurement & 1.046 & .156 & .736 & 6.697 & .000 \\
\hline
\end{tabular}

a. Dependent Variable: Accountability

Based on the results of statistical data analysis that the effect of E-Procurement Implementation on Accountability of Health Facilities Procurement in the Disaster Alert Brigade, Bantaeng Regency, table 4.30 sumarry model, explains the magnitude of the correlation value or relationship $(\mathrm{R})$ of 0.736 . The size of the influence of the independent variable or e-procurement on the dependent variable or accountability is indicated by the Adjusted R Square value of 0.529 , meaning $52.9 \%$ of the influence of the independent variable or e-procurement $(\mathrm{X})$ on the dependent variable or accountability $(\mathrm{Y})$ at the Bantaeng District Health Office. From the results, the output is at a good enough level.

This means that the implementation of e-procurement is good, so the accountability of the bureaucratic apparatus will increase. While the rest is influenced by other factors that are not explained in this study.

\section{Conclusion}

It can be said that the implementation of e-procurement at the Bantaeng District Health Office is in accordance with existing procedures. This is in accordance with the data in table 4.16. The level of government accountability at the Bantaeng District Health Office is already very good.

From the results of the calculation of the product moment correlation coefficient, the application of e-procurement has an effect on the accountability of the procurement of the Disaster Alert Brigade health facilities at the Bantaeng District Health Office. From the results of the correlation calculation, the $r$ count is 6,697 , which means that there is a relationship between the implementation of e-procurement and the accountability of the bureaucracy, and the level of the relationship is high. Then from the results of these calculations it can be seen that the coefficient of determination is $52.9 \%$.

Based on the results of hypothesis testing, namely by consulting the calculated $r$ value with the $r$ table value, and performing the $t$ test which shows that $t$ count $>t$ table $(14.827>1.685)$. This means that Ho is rejected and $\mathrm{Ha}$ is accepted, thus there is a significant influence between the application of e-procurement on the accountability of the procurement of the Disaster Alert Brigade health facilities at the Bantaeng District Health Office.

Even so, the government is expected to pay more attention to and improve the facilities and infrastructure to support the procurement of electronic medical devices. In order to 
improve the health service process, it is hoped that the employees or implementing team of the Disaster Alert Brigade will improve their disciplinary attitude. This can be done with a reward and punishment system, which is to increase employee motivation to work by providing fair and appropriate rewards and punishments.

\section{References}

[1] A. L. Prianto, "Good Governance dan Formasi Kebijakan Publik Neo-Liberal," Otoritas J. Ilmu Pemerintah., vol. 1, no. 1, Apr. 2011.

[2] S. Sedarmayanti, Sumber Daya Manusia dan Produktivitas Kerja. Bandung: CV Mandar Maju, 2009.

[3] B. Baktybayev, "Analysis of the Relationship between Women's Participation and the Rate of Corruption in the Post-Soviet States," J. Contemp. Gov. Public Policy, vol. 1, no. $1,2020$.

[4] R. Hardi and S. Gohwong, "E-Government Based Urban Governance on the Smart City Program in Makassar, Indonesia," J. Contemp. Gov. Public Policy, vol. 1, no. 1, 2020.

[5] A. Sutedi, Aspek Hukum Pengadaan Barang \& Jasa dan Berbagai Permasalahannya, 2nd ed. Jakarta: Sinar Grafika, 2012.

[6] A. Harakan, "Paradiplomasi Dalam Percepatan Pembangunan Infrastruktur Fisik dan Sosial di Kabupaten Bantaeng," J. Power Int. Relations, vol. 3, no. 1, 2018.

[7] W. Contributor, "Sistem Jemput Bola Brigade Siaga Bencana Kabupaten Bantaeng," Jaringan Invoasi dan Pelayanan Publik Sulawesi Selatan, 2018. [Online]. Available: http://jipp.sulselprov.go.id/direktori/read/103.

[8] N. Khaerah, A. Harakan, and J. Junaedi, "Call Centre Brigade Siaga Bencana Sebagai Strategi Pelayanan Kesehatan di Kabupaten Bantaeng," JDP (JURNAL Din. PEMERINTAHAN), vol. 2, no. 1, pp. 51-64, Apr. 2019.

[9] S. Rotchanakitumnuai, "The governance evidence of e-government procurement," Transform. Gov. People, Process Policy, 2013.

[10] Z. Mustapa, "Reformasi Birokrasi Melalui E-Governance: Peluang atau Tantangan Dalam Pelayanan Publik?," Otoritas J. Ilmu Pemerintah., vol. 1, no. 2, Oct. 2011.

[11] Y. C. Chen, L. T. Hu, K. C. Tseng, W. J. Juang, and C. K. Chang, "Cross-boundary egovernment systems: Determinants of performance," Gov. Inf. Q., 2019.

[12] H. P. Yuwinanto, "Implementasi E-Procurement pada Pemerintah Kota Surabaya," Jejaring Adm. Publik, vol. 5, no. 1, 2013.

[13] K. Udoyono, "E-procurement dalam Pengadaan Barang dan Jasa untuk Mewujudkan Akuntabilitas di Kota Yogyakarta," J. Stud. Pemerintah., vol. 3, no. 1, 2012.

[14] J. Wallis and F. Zhao, "e-Government Development and Government Effectiveness: A Reciprocal Relationship," Int. J. Public Adm., 2018.

[15] A. Brandon-Jones and K. Kauppi, "Examining the antecedents of the technology acceptance model within e-procurement," Int. J. Oper. Prod. Manag., 2018.

[16] A. Dwiyanto, Mewujudkan Good Governance Melalui Pelayanan Publik. Yogyakarta. Yogyakarta: UGM Press, 2008.

[17] D. Indiahono, Public Policy Base on Dynamic Policy Analysis. Yogyakarta: Gava Media, 2009. 